\title{
Phytochemistry and Antimicrobial Activity of Parthenium hysterophorus L.: A Review
}

\author{
Terefe Tafese Bezuneh \\ Department of Chemistry, Arbaminch University, Arbaminch, Ethiopia
}

Email address:

teretafe@gmail.com

\section{To cite this article:}

Terefe Tafese Bezuneh. Phytochemistry and Antimicrobial Activity of Parthenium hysterophorus L.: A Review. Science Journal of Analytical Chemistry. Vol. 3, No. 3, 2015, pp. 30-38. doi: 10.11648/j.sjac.20150303.11

\begin{abstract}
Parthenium hysterophorus is the seventh noxious alien species distributed in different part of the world. This dangerous plant is known for its negative impact on biodiversity, agriculture and human being. Parthenium plant is capable of causing allergic respiratory problems, contact dermatitis, diarrhea, skin allergy, skin rashes excessive water loss, mutagenicity, both in human and livestock. There are different attempts to control parthenium weed in which most of the methods are not successful due to rapid re-infestation of the plant. Even though parthenium plant is known for its toxicity, it is traditionally used for the treatment of fevers, headaches, wounds, diabetes, diarrhea, anemia, heart troubles and malaria to list some in different part of the world. The aim of this review article is mainly to explore the chemical components and antimicrobial property of parthenium hysterophorus. In this review the effect of parthenium on environment, human being and agriculture and major controlling practices have also been summarized.
\end{abstract}

Keywords: Parthenium hysterophorus, Phytochemistry, Antimicrobial Activity

\section{Introduction}

Parthenium hysterophorus L. is an alien invasive weed which is cited as the seventh most devastating and hazardous weed. It is a fast maturing annual herb with a deep tap root and may eventually reach a height of $2 \mathrm{~m}$. The seed of parthenium mainly disperses through flooding, water currents, movement of vehicles, machinery, livestock, grain, fodder, and to a lesser extent by wind $[1,2]$.

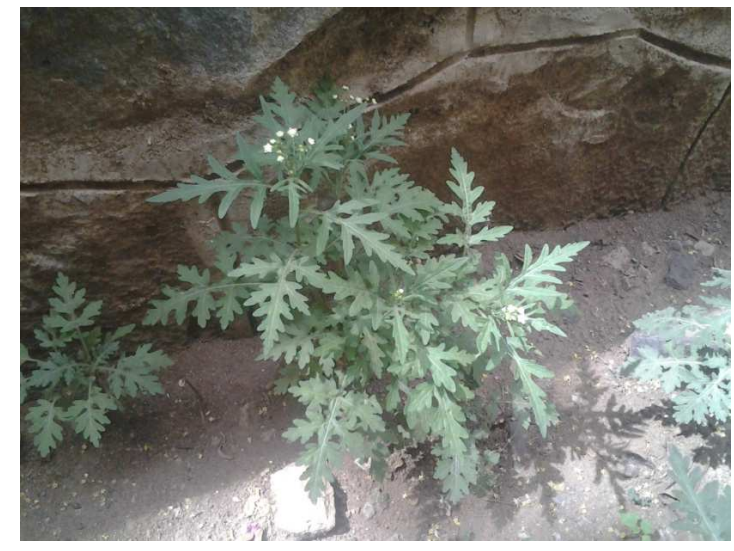

Figure 1. Matured parthenium hysterophorus plant.
Parthenium hysterophorus L. is originated as a result of natural hybridization between Parthenium confertum and Parthenium bipinnatifidum [3]. It adapts various agro-climatic conditions and almost distributed itself to variety of growing environmental conditions [4]. Some of the countries where this plant is distributed includes: India, China, Taiwan, Pakistan, Nepal, Sri Lanka, Bangladesh, Vietnam, Pacific Islands, Ethiopia, Kenya, Madagascar, South Africa, Somalia, Mozambique, Zimbabwe and several countries of South and Central America [5, 6].

This noxious weed is known for its adverse effect on environment, biodiversity, agriculture, and health of animals and human beings. This is because of the toxic chemicals produced by parthenium plant $[7,12]$.

\subsection{Impact on Biodiversity}

Different investigations have shown the treats of Parthenium on the structure and diversity of plant communities. Allelochemicals released from parthenium is capable of changing the physicochemical characteristics of the soil. It affects the moisture content, temperature, $\mathrm{pH}$, organic matter, carbon, nitrogen and phosphorus content and soil microbial activity [8-10]. The change in property of the soil due to introduction of allelochemicals affects the reproduction, 
growth and survival of other nearby plant [11-14]. Generally parthenium is intended to pose a serious threat to the biodiversity by invading new surroundings and by reducing or totally replacing the indigenous species where it causes total habitat change [15].

\subsection{Impact on Agriculture}

Parthenium is among well-known weed causing serious problem to agriculture. It reduces agricultural production by suppressing agricultural yield from crops and animals [16]. The adverse impacts of parthenium hysterophorus on agriculture have been reported by several authors. It reduces production from livestock by causing various health problems and also by causing scarcity of animal fodder by invading pasture lands. Parthenium is poisonous to livestock when it is consumed or repeatedly in contact with the weed. Those animals can encounter death, rashes on their body and udders, alopecia, loss of skin pigmentation, allergic skin reactions, dermatitis, diarrhea, anorexia, pruritus. Parthenium can also affect the psychological behavior of animals [18]. During scarcity of fodder cattles, sheeps and goats are forced to eat parthenium which can taint their meat and make diary milk unpalatable due to its irritating odor [12, 17].

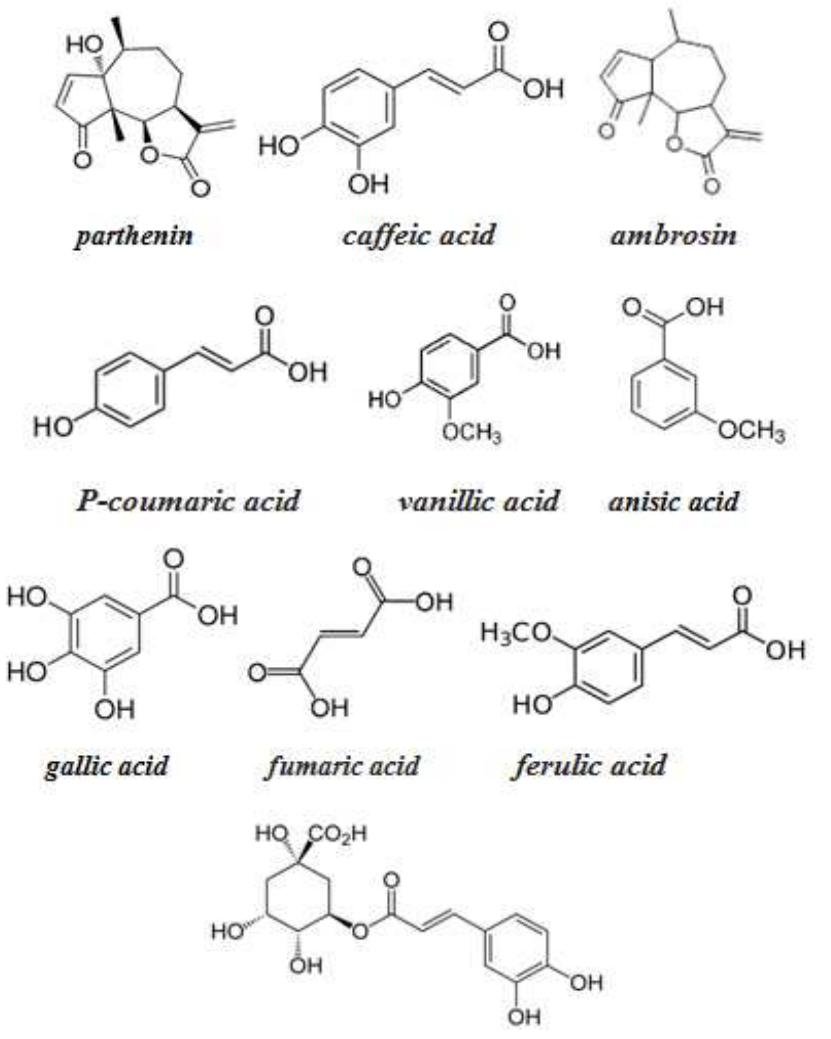

chlorogenic acid

Figure 2. Chemical structure of major allelochemicals found in parthenium plant.

The introduction of allelochemicals to the soil by any means affects the growth, reproduction and development of many plants. Allelochemicals are mostly secondary plant metabolites which may be introduced to the soil through leaching, root exudations and decay of allelophathic plants as parthenium [11]. This toxic chemical inhibits seed germination, radical growth and seedling growth which are responsible for the reduction in the distribution of other plants [20].

The major allelochemicals present in parthenium includes sesquiterpene lactones mainly parthenin and phenolic acid as: gallic acid, chlorogenic acid, ferulic acid, caffeic acid, anisic acid, vanillic acid, fumaric acid, hysterin, p-caumaric acids, hymenin, and ambrosin Figure 2 [19, 20].

Different investigations have been performed to show the impact of parthenium weed on the production of different agricultural crops. Parthenium is known by reducing the yield from agricultural crops as: wheat (triticum aestivum L.) [21], maize (Zea mays L.) [22-24], teff (erragrostic teff) [16], sorghum (Sorghum bicolor) [25], soybean (Glycine max L.) [26], cotton (Gossypium hirsutum L.) [11], haricot bean (Phaseolus vulgaris L.) [20], chickpea (Cicer arietinum) [9], tomato (Solanum lycopersicum L.) [27], radish (Raphanus sativus) [9], brassica species (Brassica campestris, Brassica olerace and Brassica rapa) $[28,23]$ to list some of them.

\subsection{Impact on Human}

There are different investigations reporting the impact of Parthenium hysterophorus on human health. Parthenium causes different health problems viz., asthma, bronchitis, contact dermatitis, eye irritation, rhinitis, hay fever, allergy, photo-dermatitis, skin rashes, peeling skin, puffy eyes, excessive water loss, swelling and itching of mouth and nose and eczema [6, 29, 30, 31].

\section{Phytochemistry of $P$. hysterophorus}

The phytochemical investigation of $P$. hysterophorus revealed the presence of various chemical constituents viz., alkaloids, proteins, saponins, tannins, carbohydrate, glycosides, terpenoids, steroids, volatile oils, amino acids, amino sugars, lignans, phenolic compounds, flavonoids, metallic elements, organic acids, terpenoids and others [32-36].

The mineral composition of $P$. hysterophorus has been analyzed by Rahmat et al. In their investigation they has showed the presence of significant amount of potassium, calcium, magnesium, sodium, iron, zinc, copper, molybdenum, lead, lithium, nickel, cadmium, chromium and manganese in parthenium plant $[37,38]$.

The phenolic acids isolated from parthenium hysterophorus plant parts extracted in different organic solvents includes: caffeic acid $\left(\mathrm{C}_{9} \mathrm{H}_{8} \mathrm{O}_{4}\right)$, p-coumaric acid $\left(\mathrm{C}_{9} \mathrm{H}_{8} \mathrm{O}_{3}\right)$, p-anisic acid $\left(\mathrm{C}_{8} \mathrm{H}_{8} \mathrm{O}_{3}\right)$, ferulic acid $\left(\mathrm{C}_{4} \mathrm{H}_{4} \mathrm{O}_{4}\right)$, fumaric acid $\left(\mathrm{C}_{4} \mathrm{H}_{4} \mathrm{O}_{4}\right)$, p-hydroxy benzoic acid $\left(\mathrm{C}_{7} \mathrm{H}_{6} \mathrm{O}_{3}\right)$, chlorogenic acid $\left(\mathrm{C}_{16} \mathrm{H}_{18} \mathrm{O}_{9}\right)$, neochlorogenic acid $\left(\mathrm{c}_{16} \mathrm{H}_{18} \mathrm{O}_{9}\right)$, protocatechuic acid $\left(\mathrm{C}_{7} \mathrm{H}_{6} \mathrm{O}_{4}\right)$, aerulic acid, and vanillic acid $\left(\mathrm{C}_{4} \mathrm{H}_{4} \mathrm{O}_{4}\right)$ [35].

Among flavovoids: quercetagetin-3,7-dimethyl ether, apigenin, kaempferol-3-o-glucoside, quercetin-3-o-glucoside, kaempferol-3-o-glucoarabinoside, luteolin, lignin, jaceidin, 
syringaresinol, santin, chrysoeriol, kaempferolglucoside, centaureidin, 6-hydroxykaempferol-3,6-dimethylether, tanetin (6-hydroxykaempferol-3,6,4-trimethylether), quercetinglucoside, 6-hydroxykempferol-3,7-dimethylether and kaempferolglucoarabinoside can be listed $[6,39,40]$.

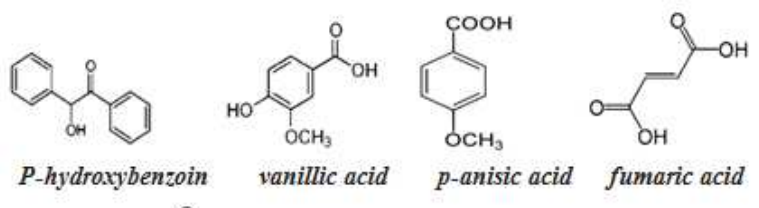<smiles>CC(=O)c1cc(/C=C/C(=O)O)ccc1O</smiles>
caffeic acid p-coumaric acid ferulic acid<smiles>O=C(O)c1cc(O)c(O)c(O)c1</smiles>

chlorogenic acid protocatechuic acid gallic acid

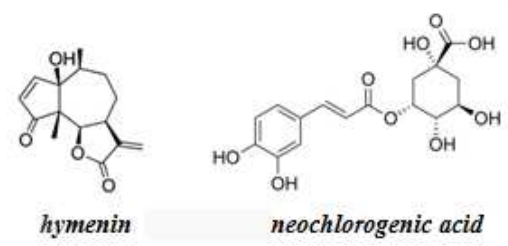

Figure 3. The molecular structure of major phenolic acids in parthenium hysterophorus $L$.<smiles>COC1=C(c2ccc(OC)cc2)Oc2cc(O)c(OC)c(O)c2C1O</smiles><smiles></smiles><smiles></smiles><smiles>COc1cc(C2OC3=CC(O)C(OC)C(O)=C3C(O)C2OC)ccc1O</smiles>

quercetin 3-O-glucoside

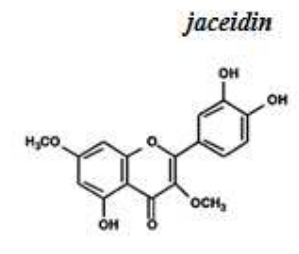

Figure 4. The molecular structure of major flavonoids in parthenium hysterophorus $L$.<smiles>C=CC(=C)CCC=C(C)C</smiles>

B-myrcene<smiles>CC(C)=CCCC(C)=CCO</smiles>

geraniol<smiles>C=C1CC/C=C(/C)CC[C@@H]2[C@H]1CC2(C)C</smiles>

\section{B-caryophyllene}<smiles>CC1=CCC(O)(C(C)C)CC1</smiles><smiles>C=C1CC[C@@]2(C(C)C)C[C@H]12</smiles>

terpinene-4-ol sabinene<smiles>C=C1C=CC(C(C)C)CCC(C)=CC1</smiles><smiles>C=CCc1ccc(O)c(OC)c1</smiles>

germacrene

eugenol<smiles>C=CC(=C)CCC=C(C)C</smiles><smiles>C=CC(=C)CCC=C(C)CCC=C(C)C</smiles><smiles>CC1=CCC2(C(C)C)CC12</smiles>

myrcene

a-femesene

a-thujene<smiles>C=C/C(C)=C\CC=C(C)C</smiles>
a-Pinene

$\beta$-ocimene<smiles>C=C1C2CCC(C2)C1(C)C</smiles><smiles>C=C1CCC2CC1C2(C)C</smiles>

camphene $\quad \beta$-pinene

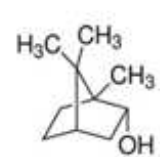

borneol

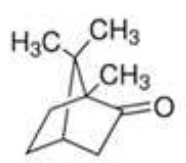

camphor<smiles>Cc1ccc(C(C)C)cc1O</smiles>

carvacrol<smiles>CC1=CCC(C(C)C)=CC1</smiles>

-terpinene
Figure 5. The chemical structure of some of the trace, minor and major oils in parthenium hysterophorus $L$.

A report from different investigations revealed the presence of trace, minor and major essential oils extracted from different plant parts of parthenium. The yield of extraction varied from $0.04-0.05 \%(\mathrm{w} / \mathrm{w})$. Trace oils extracted includes: $\alpha$-thujene, $p$-cymene, cis- $\beta$-ocimene, $\delta$-elemene, trans$\alpha$-bergamotene, $\alpha$-terpinene, dodecane, benzothiazole, nerol, $\alpha$-cubebene, tetradecane, oxo- $\alpha$-ylangene. The principal oils extracted from parthenium can be listed as: geraniol, germacrene-D, myrcene, $\alpha$-fernesene, $\beta$-caryophyllene, trans- $\beta$-ocimene, (trans, trans)- $\alpha$-farnesene, carotol, caryophyllene oxide, and 1-octen-3-ol, are the major constituents [41,42].

There are also diverse essential oils extracted from parthenium plant with lower concentrations vis., $\alpha$-pinene, camphene, $\beta$-pinene, sabinene, limonene, linalool, bicyclogermacrene, $\quad \alpha$-humulene, $\quad$ trans- $\beta$-farnesene, $\beta$-cubebene, $\quad \beta$-elemene, $\quad \beta$-phelandrene, $\delta$-cadinene, $\beta$-sesquiphelandrene, carota-5,8-diene, $\alpha$-cadinol, 3 -octanol, p-cymene, phytol (1.0\%), pentadecan-2-one, citronellol, neral, bornyl acetate, tridecane, $\beta$-bourbonene $\alpha$-terpineol $\gamma$-terpinene to list some them. Among essential oils isolated from parthenium sesquiterepenes are the principal component 
which is about $50 \%$ percent of the oil extracted. Monoterpene which is about $20 \%$ and oxygen-bearing sesquiterpenes $(6 \%)$ ranks second and third respectively $[41,42]$.
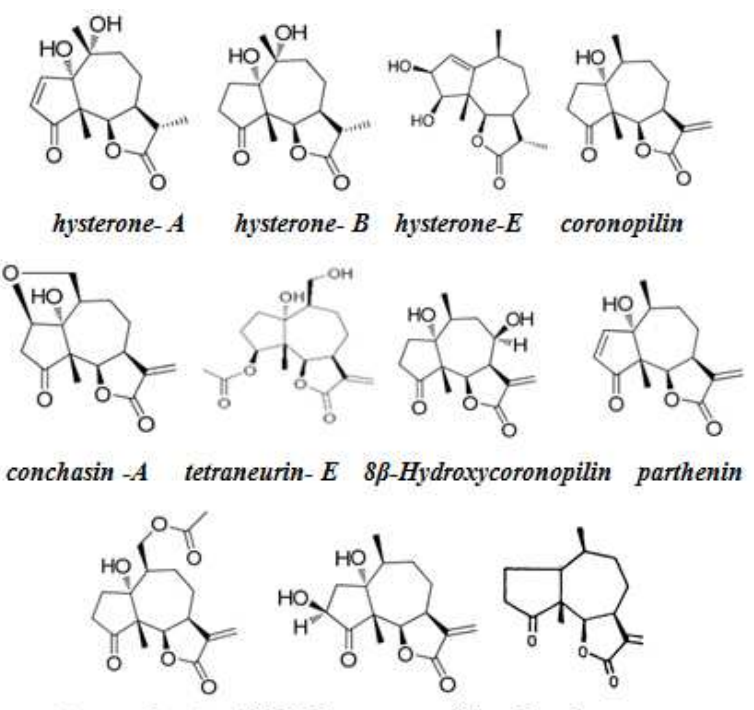

tetraneurin-A 2B-Hydroxycoronopilin damsin
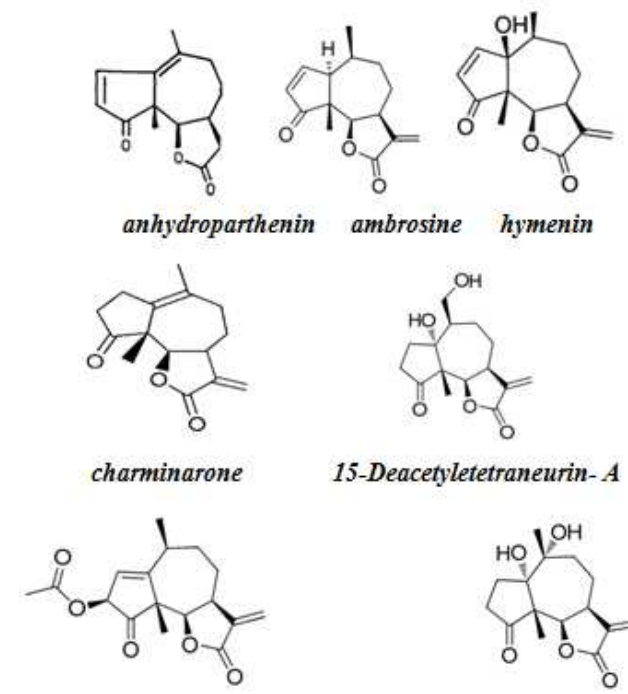

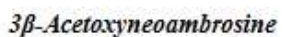

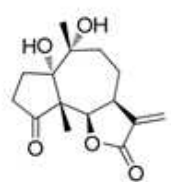

\section{2,3-Dihydro-10a-hydroxyparthenin}

Figure 6. Chemical structures of major pseudoguaianolides of parthenium hysterophorus $L$.

The extract of different parts of parthenium plant contains various pseudoguaianolide as: parthenin, anhydroparthenin, 2,3-dihydro-10 $\alpha$-hydroxyparthenin, $8 \beta$-hydroxyparthenin, ambrosin, $10 \alpha$-hydroxyparthenin, tetraneurin-A, tetraneurin-E, hymenin, 15-deacetyltetraneurin-A, damsin, $2 \beta$-hydroxycoronopilin, $8 \beta$-hydroxycoronopilin, hysterin, scopoletin, conchasin-A, 3 $\beta$-acetoxyneoambrosine, ambrosanolides,

deacetyltetraneurin-A,

$8-\beta$-acetoxyhysterone-C, 8- $\beta$-acetoxyhysterone-C, dihydroxyparthenin, acetylated pseudoguaianolide, coronopilin, 13-hydroxyparthenin, charminarone, dihydroisoparthenin,

13-methoxydihydroparthenin, balchanin, costunolide, 2 $\beta, 13 \alpha$-methoxydihydroparthenin, epoxyartemorin, 8 $\alpha$-hydroxyestaiatin, 11,13-dihydroparthenin, methoxy-11,13-d ihydroambrosin, 3- $\beta$-hydroxycostunolide, $5-\beta$ - hydroxyreynosin 13-methoxydihydroambrosin, 1$\beta$-hydroxyarbusculin, and 13-methoxy-11,13-dihydro parthenin [43-46].

\section{Antimicrobial Activity}

Even though Parthenium hysterophorus is known for its toxicity, in different parts of the world as Jamaica, Trinidad, Mexico, US Virgin Islands, Alaska and India it is used to prepare traditional medicine. Parthenium is used to treat wounds, diabetes, ulcerated sores, fever, diarrhea, anemia, heart troubles, malaria, headache, inflammatory, urinary infections, skin rashes, neurological disorder, and female reproductive problems. This can be related to the fact that parthenium produces secondary plant metabolite chemicals with potent antimicrobial activity $[49,50]$.

Plant based antimicrobials have enormous therapeutical potential and they are also cost effective as well as ecofriendly. Mostly plant based antimicrobials are free of side effects associated with synthetic antimicrobial. P. hysterophorus can be listed among various medicinal plants with potent antimicrobial property. There are so many investigations reporting the antiviral, antifungal, antibacterial, antihelmintic, antimolluscal, and antiinflammatory properties of parthenium $[47,48]$.

Antifungal property of $p$. hysterophorus has been reported by different investigators. Both plant and human pathogenic funguses viz., Fusarium Solani [51,52], Alternaria Alternata [53,54], ], Candidia albicans [56], Fusarium oxysporium [57], Aspergillus niger [57-59], Candida kefyr [56], Aspergillus flavus [60], Drechslera tetramera [59], Phoma glomerata [59], Aspergillus fumigates [37], Drechslera hawaiiensis, Alternaria alternate keissl [61], Fusarium monilifrome [61], Alternaria brassicae, Alternaria brassicicola [62], Saccharomyces cerevisiae [60], Bipolaris oryzae [63] were reported.

Antibacterial efficacy of Parthenium hysterophorus has also been reported by various scientists as: Escherichia coli [57], Bacillus subtilis, Enterococcus spp. [64], Staphylococcus aureus [58], Salmonella typhimurium, S. epidermidis, V. cholerae, Shigella flexneri [65], Pseudomonas aeruginosa [57], Micrococcus luteus [55], Bacillus cereus [60], Klebsiella pneumoniae, Enterobactor aerogenes [37], Xanthomonas vesicatoria, Ralstonia solanacearum [48].

\section{Controlling Mechanism}

There are several methods available for controlling parthenium weed. Some of the methods are: manual, chemical, bioherbicidal, biological control, competitive replacement by other plants, and managing the weed through proper utilization.

\subsection{Manual Control}

Hand weeding, plowing, firing and mowing are some of the physical or manual method of controlling the weed. Hand 
weeding is not an effective method due to several reasons. The first reason can be that, during hand pooling a matured seed will drop off and increase the area of infestation. The second reason can be related to its effect on health. Thirdly it is labor intensive and not economical and beside it needs repeated control because of the rapid re-growth of the weed. Ploughing can be considered as the best method compared to that of hand weed because of the absence of contact with weed but it has to be done before the plants reach the flowering stage. Burning and mowing or cutting the plant off at the ground level can also be used as a control strategy for parthenium weed [66].

\subsection{Chemical Control}

Chemical control is an effective and quick way of controlling parthenium weeds. Among various synthetic herbicides buctril super, chwastox, chlorimuron ethyl, metasulphuron atrazine, dicamba, picloram, glyphosate, metribuzin are to list some of them [67]. Even though, chemical control is an efficient and prompt solution of controlling parthenium weed it is not without a defect. Synthetic herbicide poses serious ecological and health problems. During application of synthetic herbicide, may be herbicide resistance weed biotype emerges and also some of the herbicides may not be selective in which it may kill untargeted plants (crops). Therefore a great care must be taken during handling and application of these chemicals [66].

\subsection{Bioherbicidal Control}

The most challenging problem with synthetic herbicides is its toxicity or the problem it cause to the environment. This fact attracts the attention to replace synthetic herbicides with naturally existing plant based herbicides. Certain plants are known for their allelophathic nature and can be used as a potent herbicide against parthenium weed. There have been different reports on the herbicidal property of different plant extracts. Some of the plants reported so far includes: Tagetes erectus [68], Dicanthium annulatum, Cenchrus pennisetiformis, Sorghum halepense [69], Azadirachta indica, Aegle marmelos, Eucalyptus tereticornis [70], Sorghum bicolor, Imperata cylindrical, Mangifera indica L. [71], Zingiber officinale, Allium cepa L., Allium sati vum L. [72], Andrographis paniculata [73], Cymbopogon citratus, Eucalyptus citrodora, Cinnamomum camphora [74, 75], Cassia occidentalis [76], Sclerotium rolfsii [77], Cophoma herbarum [78], Helianthus annuus, Oryza sativa [79], Datura metal, Nerium oleander [80] and Alstonia Scholaris [71].

\subsection{Control by Competitive Replacement}

Parthenium can also be controlled by planting competitive plants which can dominate the weed and reduce its population. This can be done by planting species like Cassia sericea, Croton bonplandianus, C. sparsiflorus, Amaranthus spinosus, Sida acuta, Tephrosia purpurea, Stylosanthes scabra, Cassia tora, Tagetes spp., Croton bonplandianum, Hyptis suaveolens, Sida spinosa, Mirabilis jalapa [81-83].

\subsection{Biological Control}

Biological control of parthenium is the most economical, environmentally safe as well as ecologically viable method. Several insects and pathogens have been tried in different parts of the world in different time. Some of the biocontrol agents utilized so far includes; Epiblema strenuana (stem-galling moth) [84], Bucculatrix parthenica (leaf-mining moth), Platphalonidia mystica (stem-boring moth), Zygogramma bicolorata (leaf feeding beetles) [85-87], Listronotus setosipennis (stem-boring weevil), Conotrachelus albocinereus (stem-galling weevil), Semicronyx lutulentus (seed-feeding weevil), Carmenta ithacae (root-boring moth), Puccinia abrupt (winter rust fungus) [88], and Puccinia melampodii (summer rust fungus) [87].

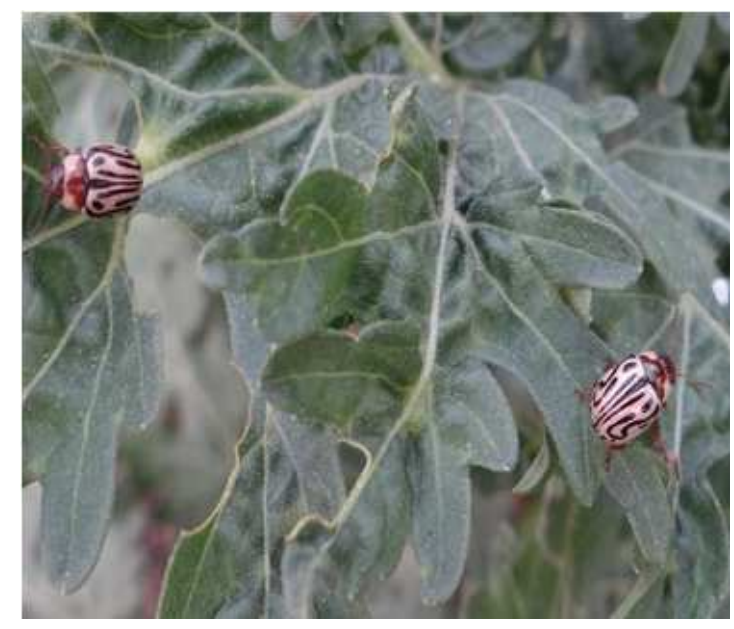

Zygogramma bicolorata

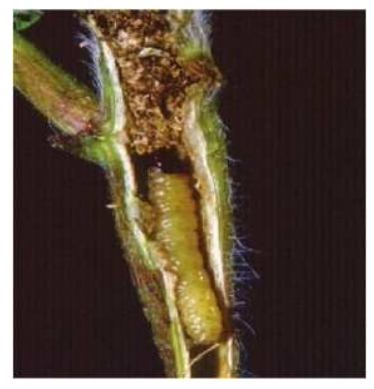

Epiblema strenuana larva

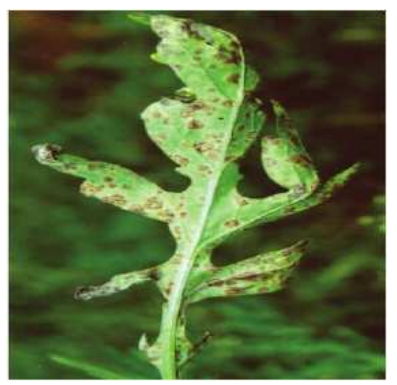

Leaf infection caused by Puccinia

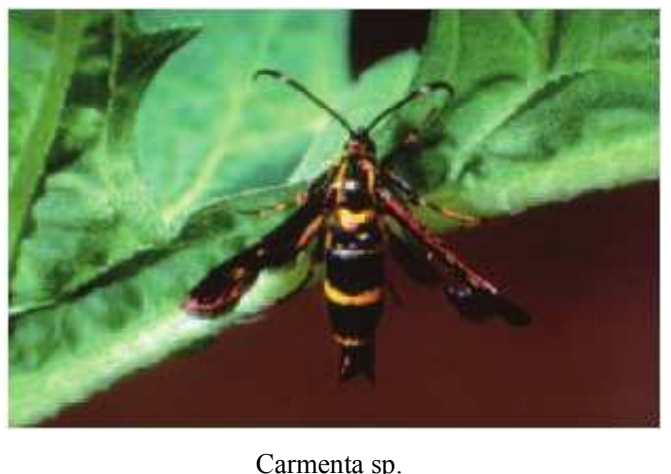

Figure 7. Damage caused by Z. bicolorata, Epiblema strenuana larva, Puccinia abrupt, Carmenta sp. on parthenium [70, 89]. 


\subsection{Controlling by Utilization}

Management by utilization is the most promising way of controlling this obnoxious weed. There are so many beneficial aspects of parthenium in which it can be used as a raw material or as additives to prepare: feed stock [90], forage [91], herbicide [92-94], pesticide [95], insecticide [96,97], ethanol [98,99], compost [100-103], green manure [104], synthesis of nanoparticles [105,106], feed additive for silkworm [107], decolorizing agent [108] can be listed among various uses of this plant.

\section{Conclusion}

Parthenium plant is mostly known for its traits on natural ecology and its adverse effect on human and animal health. There are different techniques utilized so far to control this toxic weed. The most promising way is to manage the weed by proper utilization. Parthenium plant can be used as herbicide, pesticide, insecticide and also as a row material or as additives in different industry as paper, pulp and dye industries to list some of them. Different investigation has also shown the presence of essential compounds extracted from parthenium plant with potent antioxidant, antimicrobial, anticancer properties. Therefore parthenium plant can be considered as an alternative medicinal plant if further investigation is performed.

\section{References}

[1] Seema P (2011). Harmful and beneficial aspects of Parthenium hysterophorus: an update. Biotech, 1, 1-9.

[2] Masum S M, Mirza H and Ali M H (2013). Threats of Parthenium hysterophorus on agro-ecosystems and its management: a review. International Journal of Agriculture and Crop Sciences, 6(11), 684-697.

[3] Nath R (1988). Parthenium hysterophorus L. A general account Agricultural Review, 9(4), 171-179.

[4] Annapurna C and Singh J S (2003). Variation of Parthenium hysterophorus in response to soil quality: implications for invasiveness. Weed Research, 43, 190-198.

[5] Talemos S, Abreham A, Fisseha M et al. (2013). Distribution status and the impact of parthenium weed (Parthenium hysterophorus L.) at Gedeo Zone (Southern Ethiopia). African Journal of Agricultural Research, 8(4), 386-397.

[6] Dipankar C R, Munan S (2013). Toxicology, Phytochemistry, Bioactive compounds and Pharmacology of Parthenium hysterophorus. Journal of Medicinal Plants Studies, 1(3), 126-141.

[7] Narasimhan T R, Keshava M B S, Harindranath N et al. (1984). Characterization of a toxin from Parthenium hysterophorus and its mode of excretion in animals. Journal of Bioscience, 6(5), 729-738.

[8] Binu T, Bharat B S, Maan B R, et al. (2011). Impact of Parthenium hysterophorus L. invasion on plant species composition and soil properties of grassland communities in Nepal. Flora, 206, 233-240.
[9] Daizy R B, Harminder P S, Jasvir K P, et al. (2002). Phytotoxic effect of Parthenium residues on the selected soil properties and growth of chickpea and radish. Weed Biology and Management, $2,73-78$.

[10] Ayana E, Ensermu K and Teshome S (2015). Impact of Parthenium hyterophorus L. (Asteraceae) on soil chemical properties and its distribution in a reserve area: A case study in Awash National Park (ANP), Ethiopia. Journal of Soil and Environmental Management, 6(5), 116-124.

[11] Masum S M, Ali M H, Mandal M S, et al. (2012). Influence of Parthenium hysterophorus, Chromolaena odorata and PRH on Seed Germination and Seedling Growth of Maize, Soybean and Cotton. Journal of Weed Science, 3 (1\&2), 83-90.

[12] Asad S and Rukhsana B (2006). Distribution of parthenium weed (Parthenium hysterophorus, L.), an alien invasive weed species threatening the biodiversity of Islamabad. Weed Biology and Management, 6, 89-95.

[13] Aslam F, Khaliq A, Matloob A, et al. (2014). Differential Allelopathic Activity of Parthenium Hysterophorus L. Against Canary Grass and Wild oat. The Journal of Animal and Plant Sciences, 24(1), 234-244.

[14] Rajiv P, Narendhran S, Subhash K M et al. (2013). Parthenium hysterophorus L. compost: Assessment of its Physical Properties and Allelopathic effect on Germination and Growth of Arachis hypogeae L. International Research Journal of Environment Sciences, 2(2), 1-5.

[15] Mcfadyen R E (1992). Biological control against partgenium weed in Australia. Crop Protection, 11, 405-407.

[16] Tefera T (2002). Allelopathic Effects of Parthenium hysterophorus Extracts on Seed Germination and Seedling Growth of Eragrostis tef. Journal of Agronomy and Crop Science, 188, 306-310.

[17] Pandey D K (2009). Allelochemicals in Parthenium in response to biological activity and the environment. Indian Journal of Weed Science, 41(3\&4), 111-123.

[18] Urmilesh J, Pritesh M C, Tushar T S, et al. (2011). CNS activity of methanol extract of Parthenium hysterophorus L. in experimental animals. Scholars Research Library, 3(4), 335-341.

[19] Richa P, Asvene K S, Dharm D, et al. (2015). Phenolic Acids from Parthenium hysterophorus: Evaluation of Bioconversion Potential as Free Radical Scavengers and Anticancer Agents. Advances in Bioscience and Biotechnology, 6, 11-17.

[20] Sukhada D K and Jayachandra (1979). Allelopathic Effects of Parthenium Hysterophorus L. I. Exudation of Inhibitors Through Roots. Plant and Soil, 53(1/2), 27-35.

[21] Wondimagegnehu M and Megh S (1987). Allelopathic Effect of Parthenium (parthenium hysterophorus L.) Extract and Residue on Some Agronomic Crops and Weeds. Journal of Chemical Ecology, 13(7), 1739-1740.

[22] Nganthoi D Y, Dutta B K, Romesh S et al. (2014). Allelopathic effect of Parthenium hysterophorus L. on growth and productivity of Zea mays L. and its phytochemical screening. International Journal of Current Microbiology and Applied Science, 3(7), 837-846. 
[23] Seerjana M, Bharat B S and Pramod K J (2007). Allelopathic Effects of Aqueous Extract of Leaves of Parthenium Hysterophorus L. on Seed Germination and Seedling Growth of Some Cultivated and Wild Herbaceous Species. Scientific World, 5(5), 33-39.

[24] Devi O I and Dutta B K (2012). Allelopathic Effect of the Aqueous Extract of Parthenium hysterophorus and Chromolaena Odorata on the Seed Germination and Seedling Vigour of Zea mays L. In vitro. Academic Journal of Plant Sciences, 5(4), 110-113.

[25] Tamado T, Ohlander L and Milberg P (2002). Interference by the weed Parthenium hysterophorus L. with grain sorghum: influence of weed density and duration of competition. International Journal of Pest Management, 48(3),183-188.

[26] Anteneh N, Esayas M (2011). Allelopathic effects of Parthenium hysterophorus L. aqueous extracts on soybean (Glycine max L.) and haricot bean (Phaseolus vulgaris L.) seed germination, shoot and root growth and dry matter production. Journal of Applied Botany and Food Quality, 84, 219-222.

[27] Nishanthan K, Sivachandiran S and Marambe B (2013). Control of Parthenium hysterophorus L. and its Impact on Yield Performance of Tomato (Solanum lycopersicum L.) in the Northern Province of Sri Lanka. Tropical Agricultural Research, 25(1), 56-68.

[28] Harminder P S, Daizy R B, Jasvir K P et al. (2005). Phytotoxic effects of Parthenium hysterophorus residues on three Brassica species. Weed Biology and Managements, 5, 105-109.

[29] Agarwal K K and D'Souza M (2009). Airborne contact dermatitis induced by Parthenium: a study of 50 cases in south. Indian Clinical and Experimental Dermatology, 34(5), 4-6.

[30] Lonkar A, Mitchell J C and Colnan C D (1974). Contact dermatitis from Parthenium hysterophorus L. Trans. And Annual Report of the St. John's Hospital Dermatalogical Society London, 60(7), 43-53.

[31] Sanjeev H, Bijaylaxmi S and Vinod K S (2001). Oral hyposensitization in patients with contact dermatitis from Parthenium hysterophorus. Contact Dermatitis, 44, 279-282.

[32] Lakshmanan K, Arumugam M, and Mani R (2013). In vitro analysis of phytochemical screening and antimicrobial activity of parthenium hysterophorus L. against pathogenic microorganisms. Asian Journal of Pharmaceutical and Clinical Research, 5, 41-44.

[33] Sankar N S and Dipak P (2014). Antioxidant potentials of parthenium hysterophorus L. leaf extracts. Scientific Research Journal of India. 3(2), 80-86.

[34] Shashank K, Amita M and Abhay K P (2013). Antioxidant mediated protective effect of Parthenium hysterophorus against oxidative damage using in vitro models. Complementary and Alternative Medicine, 13, 120, 1-9.

[35] Das B and Das R (1995). Chemical investigation in Parthenium hysteruphorus An-allelopathic plant. Allelopathy Journal, 2(1), 99-104.

[36] Bakhtiar M, Rashid K, Yasir A et al. (2012). Phytochemical and cytotoxic analysis of Pharthenium hysterophosis selected from District Bannu, Pakistan. African Journal of Biotechnology, 11(55), 11857-11860.
[37] Rahmat A K, Mushtaq A, Muhammad R et al. (2011). Nutritional investigation and biological activities of Parthenium hysterophorus. African Journal of Pharmacy and Pharmacology, 5(18), 2073-2078.

[38] Kanchan S D and Jayachandra (1980). Allelopathic effects of Parthenium hysterophorus L. IV. Identification of inhibitors. Plant and Soil, 55, 67-75.

[39] Abbas M N, Rana S A, Mahmood M H et al. (2013). "Phytochemical constituents of weeds: baseline study in mixed crop zone agroecosystem," Pakistan Journal of Weed science Research, 19(2), 231-238.

[40] Padma S and Deepika S (2013). "Phytochemical screening and in vitro anti-fungal investigation of Parthenium hysterophorus extracts against Alternaria alternate," International Research Journal of Pharmacy, 4(7), 190-193.

[41] Suresh C, Prubhu D, Ashok K S (1998). Partial Composition of Parthenium hysterophorus oil from Jammu Region of India. Journal of Essential Oil Research, 10, 153-155.

[42] Cíntia A M, Maria G C, Maria L C et al. (2014). Chemical Composition and Allelopathic Activity of Parthenium hysterophorus and Ambrosia polystachya Weeds Essential Oils. American Journal of Plant Sciences, 5, 1248-1257.

[43] Biswanath D, Gurram M, Yerra K R et al. (2006). Pseudoguaianolides from the Flowers of Parthenium hysterophorus. Helvetica Chimica Acta, 89, 285-290.

[44] Biswanath D, Paramesh J, Malampati S, et al. (2013). Pseudoguaianolides from a collection of the flowers of Parthenium hysterophorus Linn. (Compositae). Journal of Organic and Biomolecular Chemistry 1,195-200.

[45] Biswanath D, Saidi R V, Krishnaiah M, et al. (2007). Acetylated pseudoguaianolides from Parthenium hysterophorus and their cytotoxic activity. Phytochemistry, 68, 2029-2034.

[46] Baldev R C, Meenu J and Mandeep K B (1999). Isolation and Structure Elucidation of Some Pseudoguaianolides From Parthenium Hysterophorus. Indian Journal of Chemistry, 38(B), 1090-1092.

[47] Sesha S D M, Satyavathi K, Bhojaraju P, et al. (2013). Cytotoxic and Anthelmintic Activities of Methanolic Extract of Parthenium Hysterophorus L. Pharmacophore, 4(6), 275-279.

[48] Sukanya S L, Sudisha J, Hariprasad P et al. (2009). Antimicrobial activity of leaf extracts of Indian medicinal plants against clinical and phytopathogenic bacteria. African Journal of Biotechnology, 8(23), 6677-6682.

[49] Shashank K and Abhay K P (2014). Pharmacological activities of some common indian weeds: a review. Mintage journal of Pharmaceutical \& Medical Sciences, 3(1), 12-17.

[50] Veena B K and Shivani M (2012). Biological utilities of Parthenium hysterophorus. Journal of Applied and Natural Science, 4(1), 137-143.

[51] Shazia S, Sobiya S, (2012). Biological Control Potential of Parthenium Hysterophorus Against Fusarium Solani- A Cause of Fusarium Wilt in Potato. International Conference on Applied Life Sciences, 315-320.

[52] Zunera Z, Shazia S, Sobiya S et al. (2012). Antifungal potential of Parthenium hysterophorus L. plant extracts against Fusarium solani. Scientific Research and Essays, 7(22), 2049-2054. 
[53] Singh P and Srivastava D (2013). Phytochemical Screening and In-Vitro Antifungal Investigation of Parthenium Hystrophorus Extracts Against Alternaria Alternata. International Research journal of Pharmacy, 4(7), 190-193.

[54] Gaurav K P, Brijesh K, and Shahi S K (2013). Antifungal Activity of Some Common Weed Extracts Against Seed-Borne Phytopathogenic Fungi Alternaria Spp. International Journal of Universal Pharmacy and Life Sciences, 3(2), 6-14.

[55] Malarkodi E and Manoharan A (2013). Study on antibacterial activity of Parthenium hysterophorus L. Journal of Chemical and Pharmaceutical Research, 5(1), 134-136.

[56] Malarkodi E and Manoharan A (2013). Antifungal activity of Parthenium hysterophorus L. Journal of Chemical and Pharmaceutical Research, 5(1), 137-139.

[57] Harsha M, Santosh G and Sharda S (2011). Antimicrobial and spermicidal activities of Parthenium hysterophorus Linn. and Alstonia scholaris Linn. Indian Journal of Natural Products and Resources, 2(4), 458-463.

[58] Barsagade N B and Wagh G N (2010). Comparative screening of leaf extracts of common plants and weeds for their antibacterial and antifungal activities. Asiatic Journal of Biotechnology Resources, 3, 227-232.

[59] Rukhsana B, Afia K, and Tabinda S C (2003). Antifungal Activity of Allelopathic Plant Extracts III. Growth Response of Some Pathogenic Fungi to Aqueous Extract of Parthenium hysterophorus. Pakistan Journal of plant Pathology, 2(3), 145-156.

[60] Ajay K, Shailesh J and Tripti M (2013). Antimicrobial Potential of Parthenium Hysterophorus Linn. Plant Extracts. International Journal of Life science Biotechnology and Pharma Research, 2(3), 232-236.

[61] Rukhsana B, Sobiya S, Tehmina A et al. (2004). Antifungal Activity of Allelopathic Plant Extracts IV: Growth Response of Drechslera hawaiiensis, Alternaria alternata and Fusarium monilifrome to Aqueous Extract of Parthenium hysterophorus. International Journal of Agriculture and Biology, 6(3), 511-516.

[62] Naina S and Archana S (2012). Antifungal Activity of Allelopathic Plant Extracts: Growth Response of Alternaria Brassicae to Extract of Parthenium Hysterophorus and Lantana Camara. Journal of Environmental and Biological Science, 26(2), 133-138.

[63] Manimegalai V and Ambikapathy V (2012). Evaluation of inhibitory effects of medicinal plants extract against bipolaris oryzae of rice. Pelagia Research Library Der Pharmacia Sinica, 3(4), 507-510.

[64] Hina F, Nisar A, Ikram U, et al. (2011). Antibacterial Potential in Parthenium HYsterophorus, Stevia Rebaudiana and Ginkgo Biloba. Pakistan Journal of Botany, 43(2), 1307-1313.

[65] Siddhardha B, Ramakrishna G and Basaveswara R M (2012). In Vitro Antibacterial Efficacy of a Sesquiterpene Lactone, Parthenin From Parthenium Hysterophorus L (Compositae) Against Enteric Bacterial Pathogens. International Journal of Pharmaceutical, Chemical and Biological Sciences, 2(3), 206-209.

[66] Masum S M, Mirza H and Ali M H (2013). Threats of Parthenium hysterophorus on agroecosystems and its management: a review. International Journal of Agriculture and Crop Sciences, 6(11), 684-697.
[67] Asad S (2014). Chemical Control of Parthenium hysterophorus L. Pakistan Journal of Weed Science Research, 20(1), 1-10.

[68] Shazia S, Rukhsana B and Sobiya S (2011). Tagetes Erectus L.-A potential Resolution for Management of Parthenium Hysterophorus L. Pakistan Journal of Botany, 43(2), 885-894.

[69] Arshad J and Tehmina A (2006). Control of Parthenium Hysterophorus L., by Aqueous Extracts of Allelopathic Grasses. Pakistan Journal of Botany, 38(1), 139-145.

[70] Manpreet K, Neeraj K A, Vikas K, et al. (2014). Effects and Management of Parthenium hysterophorus: A Weed of Global Significance. Hindawi Publishing Corporation, 1-13.

[71] Arshad J (2010). Herbicidal potential of allelopathic plants and fungi against Parthenium hysterophorus-A review. Allelopathy Journal, 25(2), 331-344.

[72] Shabnam J, Arshad J and Amna S (2014). Herbicidal Activity of Some Medicinal Plants Extracts Against Parthenium hysterophorus L. Journal of Weed Science Research, 20(3), 279-29.

[73] Nagaraja T G and Deshmukh S M (2009). Phytotoxic effect of Andrographis paniculatanees on metabolism of Parthenium hysterophorus L. Journal of Biopesticides, 2(2), 165-167.

[74] Paudel V R and Gupta V N P (2008). Effect of Some Essential Oils on Seed Germination and Seedling Length of Parthenium hysterophorous L. Ecoprint, 15, 69-73.

[75] Singh H P, Batish D R, Setia N et al. (2005). Herbicidal activity of volatile oils from Eucalyptus citriodora against Parthenium hysterophorus. Annals of Applied Biology, 146, 89-94.

[76] Jai K, Disha J, Manoj S P (2011). Population dynamics of Parthenium hysterophorus (Asteraceae) and its biological suppression through Cassia occidentalis (Caesalpiniaceae). Turkish Journal of Botany, 35, 111-119.

[77] Ramanuj P, Deepika Patel and Pandey A K (2014). Herbicidal potential of agrochemicals of Sclerotium rolfsii against Parthenium hysterophorus. Journal of Pharmacy and Biological Sciences, 9(6), 44-48.

[78] Vikrant P, Verma K K, Rajak R C et al. (2006). Characterization of a Phytotoxin from Phoma herbarum for Management of Parthenium hysterophorus L. Journal of Phytopathology, 154, 461-468.

[79] Arshad J, Shazia S, Sobiya S et al. (2008). Effects of rice extracts and residue incorporation on Parthenium hysterophorus management. Allelopathy Journal, 22 (2), 353-362.

[80] Dheeba B, Sampathkumar P, Kannan M, Tamizharasi T, (2014). Comparison of Herbicidal Activity of Datura metal and Nerium oleander on the Weed, Parthenium hysterophorus in Green Gram Crop. National Academy Science Letters, 37(3), 269-274.

[81] Aneja K R (1991). "Deadly weed Parthenium hysterophorus and its control-a review," in Botanical Researches in India. Himanshu Publications, 258-269.

[82] Kandasamy O S and Sankaran S (1997). "Biological suppression of parthenium weed using competitive crops and plants," in Proceeding of the 1st International Conference on Parthenium Management. University of Agricultural Sciences, Dahrwad, India, 33-36. 
[83] Javaid A, Anjum T, and Bajwa R (2005). Biological control of Parthenium II: allelopathic efect of Desmostachya bipinnata on distribution and early seedling growth of Parthenium hysterophorus L., International Journal of Biology and Biotechnology, 2(2), 459-463.

[84] Dhileepan K (2007). Biological Control of Parthenium (Parthenium hysterophorus) in Australian Rangeland Translates to Improved Grass Production. Weed Science, 55, 497-501.

[85] Bharat B S, Khum B T, Ambika P and Uttam B S (2011). Beetle on the battle: Defoliation of Parthenium hysterophorus by Zygogramma bicolorata in Kathmandu valley, Nepal. Botanica Orientalis-Journal of Plant Science, 8, 100-104.

[86] Sushilkumar, P R (2011). Evaluation of augmentative release of Zygogramma bicolorata Pallister (Coleoptera: Chrysomelidae) for biological control of Parthenium hysterophorus L. Crop Protection, 1-5.

[87] Dhileepan K and Senaratne K W (2009). How widespread is Parthenium hysterophorus and its biological control agent Zygogramma bicolorata in South Asia? 557-562.

[88] Taye T, Einhorn G, Gossmann M, et al. (2004). The Potential of Rust as a Biological control of Parthenium in Ethiopia. Pest Mgt. J. Eth. 8, 83-95.

[89] Dhileepan K and Rachel C M (2012 P). Parthenium hysterophorus L.-Parthenium. CSIRO, 448-462

[90] Ramya R, Shree M P (2014). Comparative efficiency of pretreatment methods on Parthenium hysterophorus L., as a potential feed stock. International Journal of Scientific and Research Publications, 4(9), 1-3.

[91] Jasvir S D (2013). Foraging activity of Apis mellifera on Parthenium hysterophorus. IOSR Journal of Pharmacy and Biological Sciences, 7(5), 1-4.

[92] Daizy R B, Harminder P S, Ravinder K K (2006). Assessment of Phytotoxicity of Parthenin. Phytotoxicity of Parthenin, 62, 367-372.

[93] Subhendu D and Dinesh B S (2001). Pesticidal properties of parthenin (from Parthenium hysterophorus) and related compounds. Pest Management Science, 57, 95-101.

[94] Khan B M, Muhammad A K, Anwar N et al. (2008). Parthenium Hysterophorus L. A Potential Source of Bioherbicide. Pakistan Journal of Botany, 40(5), 1933-1942.

[95] Renga Ramanujam J, Kulothungan S, Anitha S et al. (2011). A Study on Compatibility of Pseudomonas fluorescenes L. and Parthenium hysterophorus L. as a Biocontrol agent to leaf spot by Alternaria alternata f. sp. lycopercisi in Tomato. South Asian Journal of Biological Science, 1(2), 71-86.

[96] Nisar A, Hina F, Bilal H A, et al. (2011). In vitro larvicidal potential against Anopheles stephensi and antioxidative enzyme activities of Ginkgo biloba, Stevia rebaudiana and Parthenium hysterophorous. Asian Pacific Journal of Tropical Medicine, 169-175.

[97] Tesfu F and Emana G (2013). Evaluation of Parthenium hysterophorus L. powder against Callosobruchus chinensis L. (Coleoptera: Bruchidae) on chickpea under laboratory conditions. Global Journal of Agricultural Research and Reviews, 1(1), 25-030.
[98] Preeti S Shouvik S, Shubhaneel N, et al. (2013). Dilute Acid Hydrolysis of Parthenium Hysterophorus L. for the Production of Ethanol Using Pichia Stipitis. International Journal of Energy and Power, 2(4), 88-92.

[99] Swati G, Kuntala D, Sneha S, et al. (2013). Effect of Particle Size on the Hydrolysis of Parthenium Hysterophorus L. for the Production of Ethanol. International Journal of Energy and Power, 2(1), 26-32.

[100] Prem A, Sinha S K, and Thakur P C (2010). Composting an Obnoxious Weed, Parthenium hysterophorus L., With the Help of a Millipede, Harpaphe haydeniana. Asian J. EXP. BIOL. SCI., 1(2), 337-343.

[101] Rajeshwari S, Rajiv P, and Narendhran S (2013). Parthenium Mediated Compost versus Parthenium Mediated Vermicompost: A Comparative Study of Nutrition Status. International Conference on Chemical, Agricultural and Medical Sciences, 30-33.

[102] Avnish C and Joshi P C (2010). Composting of Some Dangerous and Toxic Weeds Using Eisenia foetida. Journal of American Science, 6(3), 1-6.

[103] Sivakumar S, Kasthuri H, Prabha D et al. (2009). Efficiency of Composting Parthenium Plant anD Neem Leaves In The Presence and Absence of An Oligochaete, Eisenia Fetida. Iranian Journal of Environmental Health Science and Engineering, 6(3), 201-208.

[104] Arshad J, Sobiya S and Shazia S (2009). Comparison of Trifolium alexandrinum L. and Parthenium hysterophorus L. Green Manures in Rice-Wheat Cropping System. The Philippine Agricultural Scientist, 92(1), 110-115.

[105] Kalaiselvi M, Subbaiya R, and Masilamani S (2013). Synthesis and characterization of silver nanoparticles from leaf extract of Parthenium hysterophorus and its anti-bacterial and antioxidant activity. International Journal of Current Microbiology and Applied Science, 2(6), 220-227.

[106] Ananda S (2013). Exploitation of Parthenium Hysterophorus L. for the Rapid Biosynthesis of Silver Nanoparticles and Evaluation of their Anti-Microbial Activity. Indian Journal of Applied Research, 3(7), 79-83.

[107] Chandrakala M V, Prakash D, Patil R R, et al. (2012). Investigation on the Application of Parthenium hysterophorus Extracts as Feed Additives for Young larvae of Silkworm, Bombyx mori L. Agricultural Science Research Journals, 2(8), 449-452.

[108] Shinde U G, Metkar S K, Bodkhe R L, et al. (2012). Potential of Polyphenol Oxidases of Parthenium Hysterophorus, Alternanthera Sessilis and Jatropha curcas for Simultaneous Degradation of Two Textile Dyes: Yellow $5 \mathrm{G}$ and Brown R. Trends in Biotechnology Research, 1(1), 24-28.

[109] Surya D P Y, Kalpana M, Narendra K C et al. (2015). Assessing Physico-Chemical Parameters of Potable Water in Dhankuta Municipality of Nepal. Science Journal of Analytical Chemistry, 3(2), 17-21.

[110] Lucienne V R, Hanitriniaina R, Njaka N A et al. (2015). Laboratory Performance Evaluation in Terms of Water Analysis Through an External Quality Control. Science Journal of Analytical Chemistry, 3(2), 22-29. 